\author{
Italo Fiorin* \\ ORCID: 0000-0002-0822-9884 \\ Rzym, Włochy
}

\title{
Nowy nauczyciel, nowa szkoła
}

\section{A New Teacher, a New School}

\begin{abstract}
Summary: How can Chiara Lubich's educational thought inspire the teaching, the teacher's profile, the school's organisational model? What is fundamental to Chiara's vision is the reference to the human person, the key element of relationship. Chiara Lubich's teacher model is Jesus, the Master. The teacher-pupil relationship has, at the centre, Jesus (Jesus in the middle). The organisational model of the school is the community; a place of personal care, dialogue and fraternity. The community is inspired by family values, but it is not a closed place. It is an educational place that opens up responsibility towards others and towards society. Educating is not an academic task, but it involves getting in touch with the real world, acting for a better world.
\end{abstract}

Keywords: teaching; person; relationship; dialogue; community; fraternity.

* Prof. dr. Italo Fiorin jest nauczycielem pedagogiki i dydaktyki na Uniwersytecie LUMSA (Libera Università Maria Santissima Assunta) w Rzymie. Jest dyrektorem Studiów Podyplomowych „Wychowywać do Spotkania i Solidarności” (Scuola di Alta Formazione Educare all'incontro e alla solidarietà) oraz konsultantem Kongregacji ds. Edukacji Katolickiej. Adres: 00193 Roma, Via della Traspontina, 10, Italy; e-mail: i.fiorin@lumsa.it. 
Streszczenie: W jaki sposób myśl edukacyjna Chiary Lubich może inspirować dydaktykę, profil nauczyciela, model organizacyjny szkoły? W wizji Lubich podstawowe znaczenie nadaje się osobie ludzkiej, która jest sercem relacji. Modelem nauczyciela według Lubich jest Jezus Mistrz. Relacja nauczyciel-uczeń stawia w swoim centrum Jezusa (Jezusa pośrodku). Modelem organizacyjnym szkoły jest wspólnota, miejsce troski o człowieka, miejsce dialogu i braterstwa. Wspólnota inspiruje się wartościami rodziny, lecz nie jest miejscem zamkniętym. Jest miejscem edukacji, które wzbudza odpowiedzialność wobec innych i społeczeństwa. Nauczać to nie znaczy debatować, lecz zanurzyć się w rzeczywistości, działać, by budować lepszy świat.

Slowa kluczowe: nauczanie; osoba; relacja wychowawcza; dialog; braterstwo; wspólnota.

Dydaktyka jest wiedzą naukową, która zaliczana jest do szerokiego zakresu pedagogiki. Zajmuje się metodami i programami nauczania, byłoby jednak uproszczeniem postrzegać ją jako naukę wyłącznie praktyczną, technikę nauczania niemalże oporną na wartości. Ścisły związek z pedagogiką niezbędny jest do tego, by w podejmowaniu określonych działań miała punkt odniesienia w konkretnym modelu pedagogicznym.

Wychowanie ma dużo szersze pole znaczeniowe niż rzeczywistość szkolna, stąd nauczanie może być uważane za szczególną formę wychowania, która dokonuje się w konkretnym środowisku szkolnym i wykorzystuje specyficzne narzędzia, którymi są dyscypliny naukowe, programy i metody nauczania.

Dobra dydaktyka wychodzi poza granice szkolnej sali, nie koncentruje się wyłącznie na programie do zrealizowania oraz na wiedzy i kompetencjach do przekazania, lecz patrzy całościowo na ucznia, chce mu pomóc w realizacji życiowego projektu nie słowami, lecz konkretnie. Chociaż Chiary Lubich nie można nazwać pedagogiem, to jednak jej sposób bycia wychowawcą i pojmowania wychowania, wynikający ze świadectwa jej życia, z jej pism oraz opracowań na jej temat, może być dla dydaktyki źródłem cennych wskazań.

Zagadnienie, nad którym pragnę się pochylić w tym artykule, dotyczy wizji edukacyjnej Chiary Lubich oraz oceny tego, na ile może ona mieć pozytywny wpływ na praktykę nauczania, profil nauczyciela oraz model organizacyjny szkoły. 


\section{Wychowywać, nauczając}

Potencjał wychowania, a nie tylko nauczania, znany był Chiarze Lubich już od młodości, kiedy jeszcze nie była założycielką Ruchu Focolari i miała na imię Sylwia ${ }^{1}$. Po uzyskaniu dyplomu magistra młoda Lubich natychmiast rozpoczyna nauczanie i już od samego początku charakterystyczną cechą jej pracy dydaktycznej, świeżej i oryginalnej, była głęboko rozumiana relacja wychowawcza z dziećmi. Vincenzo Zani stwierdza: „Zagadnienia dotyczące wychowania zawsze towarzyszyły doświadczeniu Chiary: najpierw gdy była nauczycielką w trydenckich dolinach, a potem poprzez zakładanie szkół formacyjnych, wyższych instytutów, aż po niedawno utworzony Instytut Uniwersytecki Sophia”2. Bernhard Callebaut zauważa, że „biografowie jednomyślnie uznają zdolności pedagogiczne" Chiary Lubich, tak jak i inni, koledzy czy wychowankowie, którzy mogą dać o tym bezpośrednie świadectwo ${ }^{3}$.

Osobiste doświadczenie Chiary Lubich jest wymownym przykładem ścisłej relacji pomiędzy nauczaniem a wychowaniem. Nauczanie będzie krótkim epizodem w jej życiu, ale bardzo intensywnym, którego ślad będzie widoczny w całym jej zaangażowaniu dla Ruchu Focolari i które wiele razy będzie przez nią samą wspominane. Pisze: „Na nasz Ruch i na naszą historię można patrzeć jak na wielkie i niezwykłe wydarzenie wychowawcze. W Ruchu i w jego historii zawierają się wszystkie elementy wychowania i rzeczą oczywistą jest, że istnieje w nim także teoria wychowania, ściśle określona pedagogia, która stanowi podstawę naszego działania wychowawczego"4.

Zadanie nauczania, rozumiane jako szczególna forma wychowania, nie może zawężać się jedynie do przedmiotu nauki, lecz wzywa do przyjęcia szerszego horyzontu, który dotyczy projektu życia każdego ucznia. Dydaktyka jest wiedzą, która nie zamyka się w granicach szkolnego świata i ścian

${ }^{1}$ Sylwia Lubich przybrała imię Chiara w 1943 r. [zob. Armando Torno, Chiara Lubich. Życie i dzieło, thum. Krystyna Kozak (Poznań-Warszawa: Fundacja Mariapoli, Święty Wojciech, 2013), 17. Przypis thumaczy].

2 A. Vincenzo Zani, Lubich. Educazione come vita (Brescia: La Scuola, 2010), 23.

${ }^{3}$ Bernard Callebaut, La nascita dei focolari. Storia e sociologia di un carisma (Roma: Città Nuova, 2017), 87.

${ }^{4}$ Por. Chiara Lubich, „Charyzmat jedności i pedagogika. Fragment wykładu wygłoszonego 10 listopada $2000 \mathrm{r}$. na Catholic University of America w Waszyngtonie z okazji przyznania Chiarze doktoratu honoris causa z pedagogiki”, w: Chiara Lubich, Charyzmat jedności, red. Michel Vandeleene (Kraków: Fundacja Mariapoli, Wydawnictwo M, 2007), 313-314. 
klasy, lecz ma związek z życiem. Istnieje bardzo ścisły związek pomiędzy dydaktyką, edukacją i uczłowieczeniem.

Według Jacques'a Maritaina wychowywać oznacza pomóc osobie ludzkiej stać się bardziej ludzką: „Zadanie wychowania polega przede wszystkim na pomocy w dynamicznym rozwoju, przez który człowiek kształtuje się, by być człowiekiem"s. Dydaktyka stanowi ważne narzędzie tej niezbędnej pomocy, będącej szczególnym wyrazem troski. Troski o co? O to, co jest najważniejszą aspiracją każdego człowieka: pełne zrealizowanie się. Otacza się opieką nie tylko wymiar poznawczy ucznia, ale całą osobę, pamiętając także o wymiarze emocjonalnym, duchowym i aksjologicznym. Taka opieka w rozumieniu Lubich pokrywa się z zatroskaniem o to, by podarować dzieciom, nastolatkom, młodym Ideał zdolny nadać pełny sens ich życiowej przygodzie, odpowiadając $\mathrm{w}$ ten sposób na najgłębsze pragnienie każdego człowieka, które Abraham Maslow widzi w samorealizacji ${ }^{6}$, a którym dla Bruna Bettelheima jest odkrycie sensu własnego życia ${ }^{7}$.

W przemówieniu zatytułowanym „Jezus Nauczyciel”, wygłoszonym w Loppiano, przywołując znaczenie szkoły, którą Loppiano przyjęło, Lubich mówiła: „Jeśli Loppiano jest szkołą, jeśli spełnia funkcję szkoły, to jest ono szkołą bardzo wyjątkową i oryginalną. To nie książki, klasy, lekcje czynią z niego szkołę. Nie, Loppiano jest szkołą, ponieważ żyje w nim Nauczyciel"». Jezus jako Mistrz i Jezus Opuszczony (czyli ten dostrzegany w najmniejszych i ubogich) - oto początek i inspiracja koncepcji pedagogicznej Chiary Lubich.

Zadanie zaproponowane odpowiedzialnemu za nauczanie jest wymagające, ponieważ wykracza poza kompetencje zawodowe, które także są ważne. W rzeczywistości oczekiwanie wobec tego, kto, nauczając - wychowuje, jest radykalne, a polega na tym, aby inspirując się Jezusem, jedynym prawdziwym Nauczycielem, czynić relację wychowawczą relacją miłości. Tak radykalne stanowisko może być porównane do tego, które w kontekście

5 Jacques Maritain, „Od filozofii człowieka do filozofii wychowania”, w: Człowiek, wychowanie, kultura, red. Franciszek Adamski (Kraków: Wydawnictwo WAM, 1993), 61.

${ }^{6}$ Abraham Maslow, Motivation and Personality (New York: Harper Collins, 1970); por. Abraham Maslow, Motywacja i osobowość, tłum. Józef Radzicki (Warszawa: PWN, 2014).

${ }^{7}$ Bruno Bettelheim, The Uses of Enchantment: The Meaning and Importance of Fair, Tales (New York: Knopf, 1976); por. Bruno Bettelheim, Cudowne i pożyteczne: O znaczeniach $i$ wartościach baśni, thum. Danuta Denek (Warszawa: Wydawnictwo WAB, 2010).

${ }^{8}$ Chiara Lubich, Gesù Maestro. Discorso a Loppiano 17 febbraio 1971 (Rocca di Papa: Archivio Generale del Movimento dei Focolari, PDF). 
pozareligijnym zostało potwierdzone przez wybitnego naukowca naszych czasów - Edgara Morina. Mówiąc o nauczaniu, przywołuje on Platońską koncepcję erosa, „który jest jednocześnie pragnieniem, przyjemnością i miłością; pragnieniem i przyjemnością przekazania miłości do wiedzy i miłości do uczniów. Eros pozwala utrzymywać na dystans przyjemność związaną z władzą, na korzyść przyjemności związanej z darem".

Takie spojrzenie czyni nauczanie misją, misja zaś wymaga wiary. Jeżeli dla Morina ta wiara odnosi się do kultury, to dla Lubich wiara ma imię i oblicze konkretnej osoby: Jezusa Mistrza, którego należy naśladować i o którym trzeba świadczyć tak dalece, by uczniowie, a także nauczyciele czy rodzice poprzez kontakt z takimi nauczycielami mogli otworzyć się na spotkanie. Miejscem takiego spotkania jest relacja. „Wiele jest definicji dydaktyki, ale najlepiej ukazującą jej «przedmiot» jest ta, która rozumie ją jako naukę i sztukę relacji pomiędzy nauczaniem i uczeniem się w określonym kontekście"10. W tej definicji podkreśla się relację - tiret, który łączy nauczanie $\mathrm{z}$ uczeniem się. Relacja jest sercem dydaktyki.

Jak rozumieć tę relację? Trzeba wziąć pod uwagę dwa aspekty: pierwszy - wewnątrzosobowy, i drugi - międzyosobowy. Relacja wewnątrzosobowa, odnosząca się do głębi ucznia, wymaga, by nauczyciel pomógł mu zjednoczyć w sobie różne wymiary jego jako osoby: cielesny, poznawczy, emocjonalny, estetyczny, etyczny, duchowy, religijny (używając wyrażenia papieża Franciszka: pomiędzy rękoma, rozumem i sercem). Relacja międzyosobowa, czyli zewnętrzna, społeczna - dotyczy troski o relacje pomiędzy nauczycielem i uczniami, pomiędzy uczniami jako członkami jednej grupy klasowej oraz wszystkimi osobami, które tworzą tę szczególną zawodową i edukacyjną wspólnotę, jaką jest szkoła. Dzięki trosce o umysł, ręce i serce każdego wychowanka nauczanie staje się działaniem opartym na towarzyszeniu, które musi zmierzyć się z różnymi wymiarami czasu: przeszłością, przyszłością i teraźniejszością.

\section{Sztuka towarzyszenia}

Towarzyszyć - to bardzo ważne pojęcie dla edukacji, jednocześnie delikatne i mocne. Papież Franciszek pisze:

9 Edgar Morin, La testa ben fatta (Milano: Raffaello Cortina, 2000), 106.

${ }^{10}$ Italo Fiorin, La sfida dell'insegnamento (Milano: Mondadori, 2017), 3. 
Kościół będzie musiał wprowadzić swoich członków - kapłanów, zakonników i świeckich - do tej „sztuki towarzyszenia”, aby wszyscy nauczyli się zawsze zdejmować sandały wobec świętej ziemi drugiego (por. Wj 3,5). Musimy nadać naszej drodze zdrowy rytm bliskości, wraz ze spojrzeniem okazującym szacunek i pełnym współczucia, ale który jednocześnie leczy, wyzwala i zachęca do dojrzewania w życiu chrześcijańskim ${ }^{11}$.

Towarzyszenie drugiemu polega na pomocy w urzeczywistnianiu jego drogi, a nie na narzucaniu swoich oczekiwań jako ostatecznego celu.

W odniesieniu do przeszłości zadaniem każdego nauczyciela jest przekazanie dziedzictwa kulturowego. Żaden człowiek nie jest samotną wyspą i nikt nie rodzi się poza określoną kulturą, narodem czy historią. Pokolenie dorosłych ma za zadanie zachować dziedzictwo, które w określonym czasie umożliwiło wzrost i rozwój konkretnej wspólnoty. Papież Franciszek wiele razy przypomina nam znaczenie bycia narodem, wspólnotą połączoną więzią solidarności, wartościami duchowymi, społecznymi, a także artystycznymi. W inny sposób, lecz równie ważny, także szkoła, rodzina i parafia są powołane do pielęgnowania tradycji, zakorzeniania w tożsamości tak, by młode pokolenia mogły mieć poczucie przynależności. Przekazanie tego, co było i co jest uważane za ważne, rodzi poczucie przynależności do wspólnoty, sprzyja rozwojowi tożsamości, umożliwia przyjęcie zobowiązania, by nie utracić przeszłości, lecz kultywować jej wartości w nowych kontekstach życiowych, wzmacnia różne wymiary obywatelstwa. W dzisiejszym wielokulturowym i pluralistycznym społeczeństwie zadanie to nie traci swej ważności, przeciwnie - jest ubogacone; poszerza się zakres obywatelstwa, wymaga się, by osoba stała się nie tylko obywatelem własnej wspólnoty czy własnego narodu, lecz także obywatelem świata. Takie dążenie jest stale obecne w nauczaniu Lubich, ona je widzi jako część Ideału, który proponuje młodym; rzeczywistości, która odnosi się jednocześnie do metody i celu, a której na imię ,jedność".

Wychowywać nie oznacza jedynie przekazywać bogactwo kultury i wartości odziedziczone z przeszłości, które czynią nas narodem, lecz także pomóc młodym wkroczyć w przyszłość tak, by byli obywatelami świadomymi i odpowiedzialnymi za jutro. Nie jest to zadanie łatwe, podobnie jak w czasach Lubich. Tak jak wtedy, tak i dziś, może jeszcze bardziej, pokój jest zagrożony w przeważającej części naszej planety; niesprawiedliwość pogłębia podziały pomiędzy nielicznymi bogatymi a rzeszą pozbawioną środków do godnego

${ }^{11}$ Franciszek, Evangelii Gaudium (Kraków: Wydawnictwo M, 2013), nr 169. 
życia, lub wręcz do przeżycia; wznoszą się mury i powiększają nieprzyjaźnie. Wobec powyższego jeszcze bardziej wybrzmiewa prorocze wezwanie Lubich do jedności - staje się to zadaniem wychowawczym, propozycją dla młodych, którą można wyrazić tymi samymi słowami, jakimi zwróciła się do nich w marcu 1985 r. w wystąpieniu „Drogi jedności”:

Otwiera się Gen-Fest, zrodzony pod hasłem jedności, co więcej - deklarujący w swym tytule, że jest wiele dróg, które prowadzą do osiągnięcia jedności świata.

Jedność całego świata.

Kochani młodzi, czy tak bardzo jesteśmy pochłonięci codziennością, że nie dostrzegamy, iż nasze czasy są pełne napięć, wojen, bojowników, zagrożone wybuchem nuklearnym, różnorodnymi podziałami, terroryzmem, porwaniami, złem wszelkiego rodzaju, zrodzonymi z braku miłości i zgody pomiędzy ludźmi, i że wobec tego wszystkiego mówienie o jedności może wydawać się utopią? ${ }^{12}$

Rozumienie jedności jako utopii i w konsekwencji odmowa działania, co może przemienić rzeczywistość, jest pułapką, w którą wpada wielu chrześcijan, gdy myślą, że naprawdę nic nie można zmienić. Dla tych, którzy odwołują się do wartości chrześcijańskich, dramatyczna sytuacja naszych czasów powinna być sygnałem alarmowym: jaką kulturę, jaką etykę chce się rozpowszechniać i jaką uda się przekazać? Czy zawiera troskę o ubogich, uchodźców, wdowy i sieroty - czyli tych, którzy nie mają praw i są zdani na łaskę silniejszych? Czy zawiera przykład pierwszych wspólnot chrześcijańskich, w których dzielenie się zmierzało do tego, by nie było „nikogo potrzebującego"; w których zacierało się różnicę pomiędzy żydem i grekiem, mężczyzną i kobietą, niewolnikiem i wolnym? Czy zawiera słowa Jezusa o miłości nieprzyjaciół, o przebaczeniu, o miłosierdziu; a także nawoływania apostoła Pawła, by „nie odpłacać złem za zło”, lecz „zwyciężać zło dobrem” i szukać zawsze dobra między sobą i wszystkimi? Sprostanie wyzwaniom, które w związku ze światowym zjawiskiem migracji piętrzą się w naszych najbogatszych zachodnich społeczeństwach, wydaje się utopią. Lecz to właśnie wyróżnia chrześcijaństwo, że owe ewangeliczne wezwania jawią się jako nieuniknione, a weryfikują się także lub przede wszystkim w najtrudniejszych warunkach. Lubich mówi, że to, co zdaje się prawie utopią, w rze-

${ }_{12}$ Chiara Lubich, Le vie dell'unità. Messaggio al GEN-Fest, Roma, 29 marzo 1985 (Rocca di Papa: Archivio Generale del Movimento dei Focolari, PDF). 
czywistości jest fascynującym wyzwaniem. Tylko wiara w Mistrza pozwoli młodym - spadkobiercom otwartym na przyszłość - zakorzenić utopię w historii, a Ideał w rzeczywistości. To właśnie doraźne potrzeby odsłaniają prawdziwe źródła, z których czerpiemy, i pomagają odróżnić słowa od czynów. To one potrząsają naszymi sumieniami, budzą nas z odrętwienia, które obraca w banał to, co jest ideałem; w rutynę to, co jest ogniem i pasją, znieczulając i biurokratyzując nauczanie Mistrza.

\section{W obecnych czasach}

Zadanie nauczania nie ogranicza się jedynie do przekazania dziedzictwa kulturowego i wartości ani do przygotowania dzieci i młodych do życia dorosłego: relacja wychowawcza usytuowana pomiędzy przeszłością a przyszłością realizuje się w chwili obecnej; i to w teraźniejszości każdej osoby, która się uczy tu i teraz, zagwarantowana jest opieka i towarzyszenie. Konieczny jest jednak mocny związek pomiędzy odniesieniem do wartości tradycji a otwartością na przyszłość, w przeciwnym razie istnieje ryzyko takiej edukacji, w której projekt życia konstruowany jest tylko na podstawie funkcjonalnych wymogów zmieniającego się rynku, zdominowanego przez chęć zysku. Przeszłość musi być związana z przyszłością na fundamencie ambitnego planu samorealizacji, w którym wychowawcze towarzyszenie, wsparte czytelnym świadectwem życia, będzie budzić w wychowanku wolność. Ta wolność pozwoli mu z pokorną ciekawością mierzyć się z rzeczywistością, nie zatrzymując się wobec sprzeczności oraz niegodziwości własnych i innych, przyczyniając się $\mathrm{w}$ ten sposób do przemiany świata.

Relacja pomiędzy wychowawcą i wychowankiem, między mistrzem a uczniem, jest kluczowym obszarem, w którym wkład Chiary Lubich ukazuje szczególną oryginalność i płodność.

Jest wiele teorii, które - stawiając w centrum relację wychowawczą - prezentują nową dynamikę pomiędzy nauczycielem a wychowankiem. Nowością, którą odnajdujemy w doświadczeniu zrodzonym z duchowości jedności, jest relacja rozumiana nie jako rzeczywistość diadyczna [dwupodmiotowa - I. F.], lecz triadyczna [trójpodmiotowa]. Relacja, która rodzi się pomiędzy dwoma podmiotami, staje się w pewnym sensie bytem psychologicznym i społecznym (subiektywnym i obiektywnym), który jawi się jako realne tertium $^{13}$.

${ }^{13}$ Zani, Lubich, 27. 
Owo tertium może być rozumiane jako zasada społeczna, która wynika z relacji i ją wzmacnia: zasada życia społecznego i socjalizacji ${ }^{14}$. Może być rozumiane także jako jakość relacyjna, która konkretyzuje się w dialogu, widzianym w najgłębszym znaczeniu jako zasadniczy komponent bycia osobą. W dialogu bowiem dokonuje się coś więcej niż przekroczenie własnego „ja" (ubogacenie ,ja"), które do swojego rozwoju potrzebuje drugiego. Poprzez zdecentralizowanie siebie owo ,ja" uzyskuje dopełnienie. Inny ode mnie, stworzenie na obraz i podobieństwo Boga, jest bezwarunkowo przyjęty, jest tym „ty”, którego ,ja” potrzebuję. Wartość tak rozumianego dialogu jest stale obecna w koncepcji Lubich, która nieustannie przywołuje jego potrzebę, postrzegając go jako zasadniczy kierunek postępowania (,miłować wszystkich”, „miłować jako pierwsi”). Wielką nowością, którą wprowadza Lubich, jest - i to jest najgłębszy wymiar relacji wychowawczej - mocne przeświadczenie, że pomiędzy ,ja” i „ty” (,ja”-,„ty”) łącznikiem jest „Jezus pośrodku”. Utrzymywać „Jezusa pośrodku” oznacza nadać relacji bogactwo spotkania złożone z gościnności, bezwarunkowej akceptacji, zaufania, szacunku, poparcia.

W tak rozumianej relacji wychowawczej nauczyciel nie troszczy się, by kształtować drugiego w postępowym konformizmie, stawiając samego siebie jako model do naśladowania, do którego trzeba się dostosować w asymetrycznej relacji, lecz przeciwnie, wychowawca wzbudza pewną wzajemność i symetrię, która niweluje, w pewnym sensie, różnicę wieku, statusu, kultury i odpowiedzialności, ponieważ oboje: nauczyciel i uczeń, mają wspólny punkt odniesienia - Jezusa pośrodku nich. W relacji triadycznej wychowywać oznacza wychowywać siebie. To właśnie sprawia, że relacja wychowawcza w działaniu nauczyciela realizuje się przez stopniowe powierzanie uczniowi jego wzrostu, wychodzenie z zależności i uczenie się samodzielności. Ten typ relacji można nazwać autorytatywną. Ona nie oznacza zaprzeczenia autorytetu wychowawcy, lecz go wzmacnia, ponieważ postrzega on swoją odpowiedzialność jako służbę. Takie postępowanie wymaga wielkiego szacunku, wielkiej uwagi, wielkiej mądrości. Tu tkwi różnica pomiędzy tym, kto posługuje się autorytetem, aby kierować zachowaniem innych, a tym, kto się nim posługuje, aby pomóc wychowankom stać się - na ile to możliwe - niezależnymi. Taka jest różnica pomiędzy tym, kto jest autorytarny, a tym, kto jest autorytatywny: pomiędzy tym, kto w relacji powołuje się zawsze na siebie i swoją wiedzę, a tym, kto wskazuje Kogoś, kto przewyższa oboje i ku któremu kieruje się spojrzenie.

${ }^{14}$ Por. Tommaso Sorgi, Costruire il sociale (Roma: Città Nuova, 1982). 
Osobowość autorytarna domaga się bezdyskusyjnego posłuszeństwa, które wynika ze strachu przed karą; ten zaś, kto jest autorytatywny, odwołuje się do osobistej wolności i uzyskuje posłuch dlatego, że jest wiarygodny. Poza tym znaczenie słowa „,autorytet” (łac. augere - „wzrost”, „kultywować”, ,pielęgnować”, „napełniać”, „ofiarowywać z obfitością”) związane jest z pragnieniem wzrostu drugiego, nie zaś z jego uległością. Nauczać - oznacza uznać głębokie powołanie człowieka, na które nikt nie może sam odpowiedzieć, ponieważ nikt nie jest samowystarczalny; a tym bardziej małe dziecko, które potrzebuje kogoś, by towarzyszył mu w procesie jego wzrostu i pomógł mu zrealizować własne życiowe zadanie. Lecz być małym nie oznaczy być niezdolnym do przyjęcia odpowiedzialności: „,dorośli nie mają na to monopolu”. Trzeba jednak umieć zaprezentować fascynującą propozycję. Lubich pokłada wielką ufność w dzieciach i nastolatkach; widzi ich możliwości, widzi w nich autentycznych protagonistów.

\section{Nowa szkoła}

Relacja wychowawcza nie zachodzi w próżni i nie ogranicza się tylko do klasy szkolnej, lecz realizuje się w rzeczywistości - także organizacyjnej - szkoły. Refleksja pedagogiczna nad jakością nauczania odnosi się zatem do jakości kontekstu instytucjonalnego, organizacyjnego i relacyjnego, w których przebiega działanie dydaktyczne nauczycieli. Nauczyciel jest częścią pewnej zbiorowości, porusza się w środowisku społecznym, w którym działa wiele innych osób (sekretarka, dyrekcja, osoby pomocnicze). Tylko wtedy, gdy przechodzi się od fragmentarycznej organizacji szkolnej - w której każdy uczestnik działa indywidualnie, skupiony tylko na własnym zadaniu - do sieci relacji interpersonalnych, opartych na współodpowiedzialności, wspólnej pracy i wspólnych decyzjach - wartości pojedynczych osób stają się dziedzictwem wszystkich. Mowa zatem o wyborze kryteriów, na podstawie których ma być budowana tożsamość organizacyjna szkoły.

Dzisiaj bardziej niż kiedykolwiek wzrasta znaczenie efektywności. Także w odniesieniu do szkoły jej organizacja jest uwarunkowana czynnikami ekonomicznymi: poszukiwanie wydajności, optymalizacja zasobów materialnych i ludzkich, zdolność skutecznej odpowiedzi na potrzeby rynku. Taka koncepcja, która porównuje szkołę do przedsiębiorstwa, cieszy się dużym poparciem, lecz kontrastuje z wizją bardziej spójną z personalistyczną koncepcją nauczania, przedstawiającą organizację szkolną jako społeczność. W rzeczy samej, w koncepcji wspólnotowej szkoła często porównywana jest 
z rodziną. Model rodziny ma rzeczywiście wiele do zaoferowania: znajdujemy w nim miłość, oddanie się, poczucie „my”, które przeważa nad indywidualnymi interesami, współodpowiedzialność. Szkoła rozumiana jako wspólnota, inspiruje się modelem rodziny, lecz w oryginalny i swoisty sposób urzeczywistnia wartości obecne w tym modelu.

Thomas Sergiovanni proponuje listę ważnych pytań:

Co można zrobić, aby w gronie nauczycielskim wzrosło poczucie serdeczności, bliskości i współpracy? W jaki sposób możemy stać się wspólnotą zawodową w nauczaniu, w której każdy troszczy się o każdego i w której pomagamy sobie wzajemnie być, uczyć się i sprawiać, by życie zawodowe było bardziej owocne? Jakie relacje z rodzicami trzeba pielęgnować, aby czuli się częścią powstającej wspólnoty? W jaki sposób możemy pomóc jeden drugiemu? W jaki sposób możemy przekształcić sieć relacji, które zachodzą pomiędzy nami i uczniami tak, aby mogły one ucieleśnić wspólnotę? Jak możemy uporządkować nasze środowiska nauczania i uczenia się, by mogły bardziej upodobnić się do tych, które są $\mathrm{W}$ rodzinie? W jaki sposób szkoła jako grupa rodzin może upodobnić się do sąsiedztwa? Jakie wartości i podział obowiązków pomogą szkole stać się wspólnotą myśli? W jaki sposób te wartości i zadania staną się praktycznymi standardami, które posłużą jako wskazówka do tego, jak prowadzić nasze życie, czego uczyć i w jaki sposób wzajemnie się traktować? Jakie wzajemne obowiązki i zadania powstają w momencie, gdy powstaje wspólnota? ${ }^{15}$

Pytania Thomasa Sergiovanniego skierowane są przede wszystkim do nauczycieli. By zdefiniować ich wspólnotę, używa się wyrażenia „ciało” pedagogiczne. Zazwyczaj określenie to używane jest wyłącznie w sensie biurokratycznym, prawie korporacyjnym. Tu przeciwnie - ma bardzo duży ciężar gatunkowy, prawie fizyczny: nauczyciele są ,ciałem” szkoły i wobec tego wymaga się od nich jedności i współdziałania analogicznego do tego, jakie zachodzi w sensie fizycznym pomiędzy członkami „ciała”. Dąży się do tego, by praca edukacyjna była efektywna. Ale ta efektywność widziana jest jako skutek wzajemnej troski, wspólnego poszukiwania i wspólnego uczenia się.

Czy zaproponowanie modelu wspólnoty jako paradygmatu dla organizacji szkolnej nie jest już przestarzałe? Jakże wiele może nam powiedzieć o tym Chiara Lubich. Nie ma wątpliwości, że model organizacji, jaki wypływa z jej koncepcji, jest modelem wspólnoty i dobrze wiemy, jak mocne jest jej wezwanie do jedności. Oczywiście szkoła nie jest wspólnotą wiary;

15 Por. Thomas J. Sergiovanni, Costruire comunità nella scuola (Roma: LAS, 2000), 5-6. 
organizacja szkolna nie rządzi się regułami swoistymi dla stowarzyszenia czy ruchu duchowego, mimo to jest przecież miejscem wspólnotowym, gdzie osoby spotykają się i wzajemnie na siebie oddziałują. Jest miejscem, które powinno być zbudowane na podstawie odniesień kulturowych i na wartościach, miejscem, które może być pojmowane czysto biurokratycznie (relacje wyznacza obojętność i podporządkowanie się hierarchii), w sposób czysto przedsiębiorczy (relacje służbowe) lub też w sposób wspólnotowy (relacje wzajemnej akceptacji).

Chiara Lubich ubogaca ten ostatni wymiar o wartość jeszcze głębszą niż przynależność - o wartość braterstwa. W szkole kształtowanej przez wartość braterstwa klimat organizacyjny zmienia się, a logika wzajemnej pomocy zajmuje miejsce logiki współzawodnictwa. Nauczyciele i uczniowie uczą się jedni od drugich, pracując razem, zaangażowani we wspólne zadanie, którym może być badanie naukowe czy realizacja danego projektu. Wspólna praca umożliwia wymianę wiedzy, ujawnia umiejętności, docenia wkład każdej osoby jako niezbędny do realizacji wspólnego celu. Umiejętność współpracy nie jest punktem wyjścia, lecz wartością, do której się dąży i którą trzeba budować dzień po dniu, łącząc swoje wysiłki, motywacje, zasoby poznawcze, emocjonalne i wartości, którymi się dysponuje. Nauczyciel, który tworzy projekt, jest także nauczycielem, który czyni refleksję, który stawia sobie pytania, który w relacji i dialogu ze swoimi uczniami nieprzerwanie uczy się i rozwija wraz z nimi. Właśnie dlatego rzeczą słuszną jest mówić o współ-uczeniu się, a nie tylko o nauczaniu.

Za budowanie wspólnoty są odpowiedzialni nie tylko nauczyciele, odpowiedzialność ta spoczywa też na uczniach, podlegających tym samym uwarunkowaniom uczenia się; a także na ich rodzicach, którzy są współpracownikami, partnerami podzielającymi troskę o wychowanie; i personelu szkolnym obsadzonym na różnych stanowiskach. W jeszcze szerszym znaczeniu obowiązek budowy wspólnoty edukacyjnej obejmuje też inne podmioty instytucjonalne i stowarzyszeniowe działające w otoczeniu placówki.

To wielki błąd uważać szkołę wyłącznie za miejsce nauczania, którego zadaniem jest tylko zagwarantowanie realizacji szkolnych celów. Do tej instytucji edukacyjnej nie przychodzą po prostu uczniowie, lecz osoby-dzieci, nastolatkowie, młodzi; chłopcy i dziewczęta; dzieci wywodzące się z określonej rodziny, mieszkańcy określonego obszaru, związani z określonym kontekstem kulturowym aktualnym dla danego społeczeństwa. To nauczyciele muszą zdecydować, czy bycie nauczycielem ograniczą tylko do realizowania programów nauczania, czy też pogłębią je o relację uwzględniającą potrzeby swoich uczniów, nawet jeśli nie są one bezpośrednio potrzebami 
szkolnymi, lecz egzystencjalnymi. Kultura funkcjonalistyczna bowiem jest zbyt skupiona na realizacji celów i optymalizacji metod, tymczasem dojrzewające osoby nie chcą być postrzegane wyłącznie jako ,przyszli” pracownicy czy fachowcy, lecz tu i teraz szukają celu swojego życia.

Thomas Sergiovanni potwierdza, że „szkoły muszą najpierw stać się społecznościami z określonymi celami. Muszą stać się miejscami, w których członkowie stworzyli wspólnotę myśli, wiążącą ich w szczególny sposób, łączącą ich za pośrednictwem wspólnych poglądów"16.

Tym wszystkim, którzy uważają, że szkoły powinny być organizacjami zbudowanymi na wartościach wspólnoty, inspiracja pedagogiczna Chiary Lubich zapewnia idealne warunki do budowania wspólnego projektu. Jest on oparty na wartościach, w których wszyscy mogą się odnaleźć, ,zachęcając się stale nie tylko do uczenia się konkretnych przedmiotów, lecz także pragnienia dobra i obdarowywania się nim wzajemnie; zawsze zjednoczeni, nawet jeśli oddaleni, połączeni wspólnym ideałem miłości, naśladowania i wzajemnej pomocy"17.

\section{Od paradygmatu użyteczności do paradygmatu daru}

Współcześnie edukację dość często podporządkowuje się modelowi pretendującemu do udzielania odpowiedzi na wyzwania wynikające z dokonujących się przemian, zbyt wiele obiecując młodym pokoleniom. Jest to zagrożenie dla edukacji. Model ten poddaje edukację wymaganiom gospodarki. Pokazuje to wyraźnie coraz powszechniejsze przekonanie szkół o tym, że to rynek ma wyznaczać ich kierunki rozwoju, a programy nauczania mają być dostosowane do kształtowania umiejętności uważanych za niezbędne. Umiejętności, które należy rozwijać, dotyczą wiedzy uznanej za przydatną, a zatem funkcjonalną w stosunku do potrzeb rynku. Przecenianie użytecznej wiedzy nie oznacza samo w sobie zaniku innych nauk, mniej bezpośrednio przydatnych (filozofii, historii, poezji, sztuki), lecz z pewnością ich marginalizację.

Żyjemy w świecie, który kieruje się kryterium użyteczności i uzależnienia od konsumizmu. „Samego człowieka uważa się za dobro konsumpcyjne, które można użyć, a potem wyrzucić. Daliśmy początek kulturze «odrzuce-

16 Tamże, 59.

17 Por. Michele De Beni, „Una maestra speciale nel ricordo dei suoi primi alunni”, w: ESsere educatori. Coraggio di una presenza, red. Michele De Beni (Roma: Città Nuova, 2013), 29. 
nia»"18. Wyrażenie „umieć przetrwać” oznacza dziś umieć załatwić własne interesy, nieważne czy kosztem innych. Także relacje pomiędzy ludźmi kierują się interesami, użytecznością, mają nastawienia funkcjonalne.

Kultura, w której żyjemy, na wiele sposobów popycha człowieka w kierunku indywidualizmu, faworyzując autystyczny wymiar życia osobistego. Ostatecznie kultywuje się wartość samowystarczalności i pewności siebie, bez dowartościowania roli innych w zaspokojeniu potrzeb ${ }^{19}$. W takiej kulturze wydaje się, że jedyną motywacją zdolną przyciągnąć uczniów są własne interesy i zysk, który może z nich wyniknąć. A przecież ludzie nie kierują się jedynie motywacjami utylitarystycznymi i powierzchownymi, gdy angażują się tylko w to, co jest wynagradzane (przeliczając - na ogół - intensywność wysiłku do wielkości wynagrodzenia). O wiele częściej robią to (bez utylitarnych obliczeń) dla tego czegoś, co samo w sobie jest odczuwalne jako rekompensata, a także dlatego, że postrzegają daną sprawę jako bardzo ważną, nadającą głęboki sens ich życiu, satysfakcjonującą.

Chiara Lubich przypomina nam, że nauczyciel ma wielką misję, by pomóc młodym pokoleniom nie stracić z oczu tego, co jest niezbędne, ponieważ „nie samym chlebem żyje człowiek” (Mt 4,4). „Młodzi chcą się realizować oczywiście w najlepszy sposób i czują potrzebę rozwoju i wzrastania w liczbę, aby móc zaoferować ewangeliczne rozwiązania aktualnych problemów i otworzyć przyszłość dla tych, którzy stracili nadzieję"20. To właśnie pozwala jej skierować do młodych porywające i wymagające przesłanie, ponieważ wie, że oni w swoich sercach pielęgnują gotowość, by budować lepszy świat:

Powiem wam prawdę, że nie mogę nie mieć nadziei.

Czy młodzi chcą uchronić zasadnicze wartości życiowe, godność człowieka, pokój, naturę?

Bogu niech będą dzięki! Jeśli tak jest, są na dobrej drodze.

Czy do młodych należy nowa cywilizacja jedności, która formuje się, w większości nieświadomie, siłą rzeczy?

18 Franciszek, Evangelii Gaudium, n. 53.

19 Por. Zygmunt Bauman, Homo consumens (Trento: Erickson, 2007); Zygmunt Bauman, Capitalismo parassitario (Bari: Laterza, 2009); Commisione Europea, Insegnare ad apprendere. Verso la società conoscitiva (Bruxelles - Lussemburgo: CECA-CE-CEEA, 1995); Jacques Delors, Learning: the treasure within (Paris: UNESCO, 1996).

${ }^{20}$ Lubich, Le vie. 


\section{Bogu niech będą dzięki!}

I choć, nie sposób nie zauważyć wieloznaczności, która kryje się pod tymi wszystkimi zjawiskami, musimy potwierdzić, że widać tu przygotowany teren, który jutro może uczynić realnym zjednoczenie świata. Wystarczy, z pomocą Boga, dać z siebie wszystko, by skierować nowe tendencje młodych ku dobru ${ }^{21}$.

Wobec kultury konkurencyjnego indywidualizmu, będącej, jak przypomina papież Franciszek, ,kulturą odrzucenia” i zagrażającej naszemu człowieczeństwu, zadanie wychowawców i nauczycieli jest jasno sprecyzowane: wymagać, zaproponować młodym nie tyle ograniczone perspektywy rynkowe, ile wielki horyzont wartości, z odpowiedzialnością za wyznaczanie, w wiarygodnej formie, innej drogi, nowej motywacji, bo to właśnie oznacza mieć odwagę, by pójść pod prąd.

To nie przypadek, że dzisiaj coraz więcej nauczycieli będących w Ruchu Focolari wykazuje szczególne zainteresowanie takim podejściem pedagogicznym, które w programach nauczania uwzględnia formację do dobra wspólnego i proponuje uczniom możliwość angażowania się w projekty stanowiące konkretną odpowiedź na liczne potrzeby zauważalne w różnych środowiskach życia. Takie podejście znane jest pod angielską nazwą Service-Learning (uczenie się poprzez służenie) czy też w języku hiszpańskim Aprendizaje y Servicio Solidario (uczenie się i solidarna służba) ${ }^{22}$.

Służenie jest doświadczeniem solidarności, które zawiera narodziny relacji, więzi, wymagającej bezpośredniej odpowiedzialności oznaczającej prawdziwe zrozumienie tego, czego drugi rzeczywiście potrzebuje, a nie projektowania na niego naszych marzeń i naszych oczekiwań. Solidarna służba, która odpowiada na rzeczywiste zapotrzebowania innych, rodzi zawsze pewną strukturę wzajemności, gdzie ten, kto podarowuje, otrzymuje od „beneficjenta” coś dla siebie i dla swojego procesu uczenia się. W ten sposób unika się ryzyka relacji zależności, a wchodzi się w dynamikę wzajemnej promocji ${ }^{23}$.

\section{Tamże.}

22 Service-Learning [uczenie się przez służenie] to podejście propagujące działania na rzecz własnej społeczności, włączone w program nauczania. [Por: Nieves Tapia, Educazione e solidarietà (Roma: Città Nuova, 2006); Oltre l'aula. La proposta pedagogica del Service Learning, red. Italo Fiorin (Mediolan: Mondadori, 2017)].

${ }^{23}$ Carina Rossa, „Apprendere è servire”, w: Essere educatori. Coraggio di una presenza, red. Michele De Beni (Roma: Città Nuova, 2013), 130. 
Nieustanne odniesienie do Jezusa Mistrza pozwala Lubich rozświetlić zadania wychowawcze poprzez nadanie głębszego znaczenia kluczowym terminom dyskursu pedagogicznego: „osoba”, „wspólnota”, „,braterstwo”. W jej wizji fundamentalne jest odniesienie do osoby ludzkiej, stanowiącej serce relacji wychowawczej, dla której jako interpretacyjny paradygmat Lubich proponuje Trójcę Świętą (relację triadyczną, Jezus pośrodku). Wspólnota rodzi się z braterskiej relacji pomiędzy osobami. Nie chodzi tu jednak o pielęgnowanie jakiejś wzniosłej wizji wspólnoty, lecz o postrzeganie braterskiej wspólnoty jako miejsca wychowania, które otwiera na odpowiedzialność wobec drugich i społeczeństwa.

W środowisku szkolnym braterstwo stanowi fundament edukacji na rzecz aktywnego obywatelstwa i dobra wspólnego, dziś, bardziej niż kiedykolwiek, pilnej i koniecznej. W trwającym procesie globalizacji myśl Chiary o braterstwie ukierunkowuje na uczenie się umiejętności budowania braterskich odniesień w jedności-odrębności - zarówno w wymiarze mikro-, jak i makrospołecznym: pomiędzy osobami, wspólnotami, ludami, grupami etnicznymi, narodami, państwami, religiami, instytucjami ${ }^{24}$.

Braterstwo coraz szerzej otwiera oczy i serce; jest korzeniem, z którego wyrasta zaangażowanie do przemiany rzeczywistości, budowania lepszego świata; zaangażowanie i odpowiedzialność, które rodzą aktywne obywatelstwo. Papież Franciszek często mówi o potrzebie takiego Kościoła, który nie zamyka się w wąskich granicach swojego bezpieczeństwa, lecz „wychodzi” ku peryferiom świata, by być blisko ludzi naszych czasów, przede wszystkim najbiedniejszych i najsłabszych. Nauczanie to nie dysputa, obserwowanie świata z balkonu, lecz zanurzenie się w rzeczywistości.

\section{Wnioski}

Zamysłem tego artykułu było wyeksponowanie niektórych aspektów wizji pedagogicznej Chiary Lubich, mających wpływ na dydaktykę, w celu wzbudzenia refleksji oraz ukazania kierunku zaangażowania dla tych, którzy z odpowiedzialnością działają w obszarze edukacji szkolnej.

Zobaczyliśmy, że dla Chiary Lubich relacja pomiędzy osobami, oparta na miłości wzajemnej, stanowi serce relacji wychowawczej pomiędzy na-

${ }^{24}$ Zani, Lubich, 32. 
uczycielami i uczniami. I dalej: że braterstwo jest podstawową wartością społeczności zawodowej i edukacyjnej. Wykazaliśmy także, że wychowanie poprzez nauczanie przybiera postać towarzyszenia w drodze ku przyszłości, zapraszającego nieustannie do odpowiedzialności wobec dobra wspólnego.

Profil nauczyciela, który wyłania się z lektury Chiary Lubich, jest odbiciem modelu jedynego prawdziwego Mistrza, Jezusa, modelu autorytetu wolnego od autorytaryzmu, braterstwa wolnego od sentymentalizmu, bezwarunkowej akceptacji najuboższych i najsłabszych wolnej od zależności; modelu całkowitego poświęcania się.

\section{Ttumaczenie: Mariola T. Kozubek, Stanisław Grochmal, Matgorzata Radomska}

\section{Bibliografia}

Bauman, Zygmunt. Capitalismo parassitario. Bari: Laterza, 2009.

Bauman, Zygmunt. Homo consumens. Trento: Erickson, 2007.

Bettelheim, Bruno. Cudowne i pożyteczne: O znaczeniach $i$ wartościach baśni. Tłum. Danuta Denek. Warszawa: Wydawnictwo WAB, 2010.

Callebaut, Bernard. La nascita dei focolari. Storia e sociologia di un carisma. Roma: Città Nuova, 2017.

Commisione Europea. Insegnare ad apprendere. Verso la società conoscitiva. Bruxelles-Lussemburgo: CECA-CE-CEEA, 1995.

De Beni, Michele. „Una maestra speciale nel ricordo dei suoi primi alunni”. W: Essere educatori. Coraggio di una presenza, red. Michele De Beni, 28-31. Roma: Città Nuova, 2013.

Delors, Jacques. Learning: the treasure within. Paris: UNESCO, 1996.

Fiorin, Italo. La sfida dell'insegnamento. Milano: Mondadori, 2017.

Franciszek. Evangelii Gaudium. Kraków: Wydawnictwo M, 2013.

Lubich, Chiara. „Charyzmat jedności i pedagogika. Fragment wykładu wygłoszonego 10 listopada 2000 r. na Catholic University of America w Waszyngtonie, z okazji przyznania Chiarze doktoratu honoris causa z pedagogiki". W: Chiara Lubich, Charyzmat jedności, red. Michel Vandeleene, 313-320. Kraków: Fundacja Mariapoli, Wydawnictwo M, 2007.

Lubich, Chiara. Gesu Maestro. Discorso tenuto a Loppiano 17 febbraio 1971. Rocca di Papa: Archivio Generale del Movimento dei Focolari.

Lubich, Chiara. Le vie dell'unità. Messaggio al Gen-Fest, Roma, 29 marzo 1985. Rocca di Papa: Archivio Generale del Movimento dei Focolari. 
Maritain, Jacques. „Od filozofii człowieka do filozofii wychowania”. W: Człowiek, wychowanie, kultura, red. Franciszek Adamski, 61-79. Kraków: Wydawnictwo WAM, 1993.

Maslow, Abraham. Motywacja i osobowość. Tłum. Józef Radzicki. Warszawa: Wydawnictwo Naukowe PWN, 2014.

Morin, Edgar. La testa ben fatta. Milano: Raffaello Cortina, 2000.

Oltre l'aula. La proposta pedagogica del Service Learning, red. Italo Fiorin. Milano: Mondadori, 2017.

Rossa, Carina. „Apprendere è servire”. W: Essere educatori. Coraggio di una presenza, red. Michele De Beni, 128-134. Roma: Città Nuova, 2013.

Sergiovanni, Thomas J. Costruire comunità nella scuola. Roma: LAS, 2000.

Sorgi, Tommaso. Costruire il sociale. Roma: Città Nuova, 1982.

Tapia, Nieves. Educazione e solidarietà. Roma: Città Nuova, 2006.

Torno, Armando. Chiara Lubich. Życie i dzieło. Tłum. Krystyna Kozak. Poznań-Warszawa: Fundacja Mariapoli, Święty Wojciech, 2013.

Zani, A. Vincenzo. Lubich. Educazione come vita. Brescia: La Scuola, 2010. 